\title{
Historical aspects of osteochondral junction studies in perinatal autopsies
}

\begin{abstract}
Microscopic examination of the fetal ribs' osteochondral junction (OCJ) during perinatal autopsies is a reliable method to determine intrauterine fetal growth abnormalities. The ribs are ideal bones for studying fetal growth and development as they have the highest growth from a linear point of view during intrauterine life and are easy to access during autopsy examination. Understanding the normal histology of rib bones at different gestational ages is fundamental to recognize the postmortem pathological alterations. Moreover, examination of the OCJ can help to estimate the timing of the intrauterine insult that ultimately leads to the perinatal death.
\end{abstract}

Keywords: autopsy, asteochondral junction, ribs
Volume 2 Issue 2 - 2017

\author{
Ana Karina Marques Salge,' Janaína Valadares \\ Guimarães,' 'Flaviana Vieira,' Karina Machado \\ Siqueira,' Renata Calciolari Rossie Silva, ${ }^{2}$ \\ Douglas Reis Abdalla, ${ }^{3}$ George Kemil \\ Abdalla, ${ }^{3}$ Eumenia Costa Da Cunha Castro ${ }^{4}$ \\ 'Goiás Federal University, Brazil \\ ${ }^{2}$ Oeste Paulista University, Brazil \\ ${ }^{3} T a l e n t o s$ Humanos University, Brazil \\ ${ }^{4}$ Texas Children's Hospital and Baylor College of Medicine, USA
}

Correspondence: Ana Karina Marques Salge, Nursing School, Goiás Federal University, Goiânia, Goiás, Brazil, Tel 55-62-32096280, Fax 55-62-3209-6282, Email anasalge@gmail.com

Received: February 03, 2017 | Published: March 02, 2017

\section{Introduction}

Through analysis of the fetal ribs' osteochondral junction (OCJ), it is possible to investigate abnormalities of the fetal growth that may be directly associated with the mechanism that led to death. The first studies on rib's OCJs were carried out in the area of plastic surgery and oral surgery, with the aim to study the OCJ cartilage growth type and to improve the quality of mandibular grafts using rib fragments. ${ }^{1-7}$ Rib's OCJs from stillbirths began to be studied in the beginning of the 1960 's, and these studies correlated OCJ morphological alterations with nutritional disorders, such as rickets. In addition, it was determined that intercurrences during pregnancy could cause changes to the OCJ, and that it would be possible to estimate the duration of intrauterine stress by analyzing the OCJ..$^{8-13}$

\section{Discussion}

In studies performed in unexpectedly dead children, $60 \%$ of births before the $32^{\text {nd }}$ week of gestation and $75 \%$ of early preterm births showed evidence of rib abnormalities at the autopsy examination. ${ }^{14-16}$ Other studies, in patients diagnosed with Sudden Infant Death Syndrome demonstrated that morphological abnormalities of the OCJ could be used as a parameter to assess the duration and presence of prior diseases in these children. ${ }^{9,17}$ Moreover, OCJ abnormalities have been demonstrated in patients without primary growth disturbance but with oral and dental malformations, as well as in premature patients with hyaline membrane disease. ${ }^{11,12}$

In experimental studies, OCJ changes have been related to infectious processes, and it has been shown that early onset OCJ alterations are increased in rats subjected to intrauterine stress. ${ }^{18}$ The ribs are ideal bones for studying intrauterine fetal growth and development as they have the highest growth from a linear point of view during intrauterine life and are easy to access during autopsy examination. The ribs are the place where changes in bone growth are first identified and have similar morphological changes to those found in longer bones. ${ }^{10,19}$
OCJ length in the $5^{\text {th }}$ and $6^{\text {th }}$ rib at birth is $120 \mathrm{~mm}$; considering total gestation time, the OCJ growth pattern is approximately $220 \mu \mathrm{m}$ per day. ${ }^{10}$ Sets of cartilaginous cells are constantly deposited in the fetus's extracellular matrix throughout intrauterine development. ${ }^{10}$ Several factors influence skeletal growth, maturation, and bone mass acquisition in newborns and infants, with a close and complex relationship between them. These factors are: genetic, nutritional, sexual, hormonal, local growth factors, and physical activity. ${ }^{20-23}$ These same factors seem to play a role in intrauterine growth and studies published in the past ten years suggest that OCJ abnormalities were more commonly associated with congenital malformations, maternal diseases and/or placental abnormalities. ${ }^{24,25}$

The OCJ is formed by cartilage, free bone marrow zone, and newly formed bone. The cartilage grows in a linear fashion; cells increase in size in the hypertrophic layer and "burst" at the junction laying down cartilaginous matrix for endochondral bone formation. ${ }^{24-28}$ The expression of specific genes that regulate the hypertrophy rate of the chondrocytes and the expression of the cartilage oligomeric matrix protein (COMP) have an important role in the ossification process leading to skeletal growth and acquisition of bone mass in the newborn and children. ${ }^{28}$

The lesions in the OCJ show a temporal pattern that helps estimating the length of the intrauterine insult. ${ }^{24}$ Studies reported that the earliest lesions are characterized by lack of bone marrow free zone, followed by hematopoietic elements in close proximity to the cartilage columns. ${ }^{24}$ Afterwards, the presence of bridging in between the cartilage columns and finally complete lack of organization of the OCJ seem to support a lengthy period of intrauterine disease. ${ }^{24,25}$

In the literature, the incidence of abnormal OCJ in perinatal autopsies was $62 \% .{ }^{24}$ Intrauterine growth restriction was associated most often with banding. Disorganization of OCJ, named "bizarre" by the authors, was more frequently noticed in premature fetuses and associated with severe placental abnormalities such as massive perivillous fibrinoid deposition and complex fetal congenital abnormalities. ${ }^{24}$ 


\section{Conclusion}

OCJ morphological abnormalities are frequent in perinatal autopsies, and the different morphological patterns correlate with the timing of the intrauterine insult and may be helpful in determining the underlying cause of death.

\section{Acknowledgements}

None.

\section{Conflict of interest}

The author declares no conflict of interest.

\section{References}

1. Sarnat BG. Facial and neurocranial growth after removal of the mandibular condyle in the Macaca rhesus monkey. Am J Surg. 1957;94(1):1920 .

2. Meikle MC. In vivo transplantation of the mandibular joint of the rat: an autoradiographic investigation into cellular changes at the condyle. Arch Oral Biol. 1973;18(8):1011-1012.

3. Ware WH, Browm SL. Growth center transplantation to replace mandibular condyles. J Maxilofac. 1981;9(1):50-56.

4. Kantomaa T. The role of the mandibular condyle in the facial growth. Proc Finn Dent. 1984;80(Suppl 9-11):1-57.

5. Copray JC, Dibbets JM, Kantomaa T. The role of condylar cartilage in the development of the temperomandibular joint. Angle Orthod. 1988;58(4):369-372.

6. Peltomaki T, Isotupa K. The costochondral graft: a solution or a source of facial asymmetry in growing children. A case report. Proc Finn Dent Soc. 1991;87(1):167-174.

7. Peltomaki T, Quevedo LA, Jeldes G, et al. Histology of surgically removed overgrown osteochondral rib grafts. J Craniomaxillofac Surg 2002;30(6):355-360.

8. Epker BN, Frost HM. Biomechanical control of bone growth and development: a histologic and tetracycline study. J Dent Res. 1966;45(2):364370 .

9. Sinclair Smith C, Dinsdale F, Emery J. Evidence of duration and type of illness in children found unexpectedly dead. Arch Dis Child. 1976;51(6):424-429.

10. Emery JL, Kalpaktsoglou PK. The costochondral junction during later stages of intrauterine life, and abnormal growth patterns found in association with perinatal death. Arch Dis Child. 1967;42(221):1-13.

11. Jones R, Bahn RC, Randall R, et al. The human costochondral junction. I. Patients without primary growth disturbances. Mayo Clin Proc. 1969;44(5):324-329.

12. Robertson B, Ivemark B. Abnormalities of the costochondral junction in cases of perinatal death, with special reference to hyaline membrane disease. Acta Path Microbial Scan. 1969;77(1):172-175.
13. Shimomura Y, Wezeman FH, Ray RD. The growth cartilage plate of the rat rib: cellular differentiation. Clinical Orthopaedics and Related Research. 1973;90:246-255.

14. Emery JL. The assessment of the duration of illness in children unexpectedly dead. Med Sci Law. 1964;14:39-42.

15. Buck GM, Cookfair DL, Michalek AM, et al. Intrauterine growth retardation and risk of sudden infant death syndrome (SIDS). Am J Epidemiol. 1989;129(5):874-84.

16. Williams SM, Taylor BJ, Ford RP, et al. Growth velocity before sudden infant death. Arch Dis Child. 1990;65(12):1315-1318.

17. Byard RW, Foster BK, Byers S. Immunohistochemical characterization of the costochondral junction in SIDS. J Clin Pathol. 1993;46(2):108112 .

18. Pratt CW, Mccance R. Severe under nutrition in growing and adult animals. Brit J Nutr. 1960;14(4):75-79.

19. Fazzalari NL, Moore AJ, Byers S, et al. Quantitative analyses of trabecular morphogenesis in the human costochondral junction during the postnatal period in normal subjects. The Anatomical Record. 1997;248(1):112.

20. Del Rio L, Carrascosa A, Pons F, et al. Bone mineral density of the lumbar spine in white Mediterranean Spanish children and adolescents: changes related to age, sex, and puberty. Pediatr Res. 1994;35(3):362326 .

21. Carrascosa A, Gussinye M, Yeste D, et al. Bone mass acquisition during infancy, childhood and adolescence. Acta Paediatr Suppl. 1995;9(411):18-23.

22. De Luca F, Baron J. Control of bone growth by fibroblast growth factors. Trends Endocrinol Metab. 1999;10(2):61-65.

23. Colnot C, Romero DM, Huang S, et al. Mechanisms of action of demineralized bone matrix in the repair of cortical bone defects. Clin Orthop Relat Res. 2005;(435):69-78.

24. Cunha Castro EC, Popek EJ. Osteochondral junction lesions in stillborn fetuses and their relationship to autopsy diagnoses. Early Hum Dev. 2007;83(9):593-599.

25. Salge AK, Evangelista TB, Canno RC, et al. Morphological and morphometrical alterations of the osteochondral junction in perinatal necropsies. Ann Diagn Pathol. 2008;12(6):397-400.

26. Carlsen S, Hansson AS, Olsson $\mathrm{H}$, et al. Cartilage oligomeric matrix protein (COMP)-induced arthritis in rats. Clin Exp Immunol. 1998;114(3):477-484.

27. Giannoni P, Siegrist M, Hunziker EB, et al. The mechanosensitivity of cartilage oligomeric matrix protein (COMP). Biorheology. 2003;40(1):101-109.

28. Wong M, Siegrist M, Goodwin K. Cyclic tensile strain and cyclic hydrostatic pressure differentially regulate expression of hypertrophic markers in primary chondrocytes. Bone. 2003;33(4):685-693. 